\title{
TRIPARTÍCIA TRESTNÝCH ČINOV MEDZIVOJNOVEJ ČESKOSLOVENSKEJ REPUBLIKY ${ }^{1}$
}

\section{THE TRIPARTITE OF CRIMINAL OFFENCES IN INTERWAR CZECHOSLOVAK REPUBLIC}

\author{
Miroslav Fico \\ Univerzita Pavla Jozefa Šafárika v Košiciach, Právnická fakulta \\ https://doi.org/10.33542/SIC2019-2-05
}

\begin{abstract}
ABSTRAKT
Po vzniku Československej republiky platil na našom území v oblasti trestného práva právny dualizmus. Vychádzal z ustanovení tzv. recepčnej normy, a teda v českej časti republiky platili rakúske právne predpisy (predovšetkým zákon č. 117/1852 ř. z. o zločinoch, prečinoch a priestupkoch) a na územi Slovenska a Podkarpatskej Rusi predpisy uhorské (hlavne zák. čl. V/1878 - trestný zákon o zločinoch a prečinoch, zák. čl. XL/1879 o priestupkoch). Autor sa $v$ článku snaži o zachytenie snáh o unifikáciu odvetvia trestného práva, s dôrazom na delenie trestných činov vjednotlivých návrhoch unifikovaných trestných zákonov v medzivojnovej Československej republike.
\end{abstract}

\begin{abstract}
The field of criminal law applied legal dualism in our country after the formation of the Czechoslovak Republic. Legal dualism was grounded in the provisions of a so-called receptive standard, i.e. the Czech part of the republic applied Austrian legal regulations (mainly Act No. 117/1852 Coll. on crimes, misdemeanours and delicts), and the Slovak territory and Subcarpathian Russia applied Hungarian regulations (mainly Act Section V/1878 - Criminal Law on crimes and misdemeanours, Act Section XL/1879 on Delicts). The author tries to depict all efforts to unify the field of criminal law, with emphasis on types of crime offences in drafts of unified Criminal Codes in interwar Czechoslovak republic.
\end{abstract}

\section{I. ÚVOD}

Po vzniku Československej republiky bol 28. októbra 1918 A. Rašínom pripravený zákon o zriadení samostatného štátu československého, ktorý vyšiel pod číslom č. 11/1918 Zb. z. a n. Táto tzv. recepčná norma vo svojom čl. 2 stanovila, že ,, všetky doterajšie zemské a rišske zákony a nariadenia zostávajú dočasne v platnosti “. Ustanovenia recepčnej normy znamenali pre novovzniknutú republiku stav právneho dualizmu (v počiatkoch dokonca trializmu). V Čechách, na Morave a Sliezsku tak po vzniku republiky platili rakúske právne predpisy, a to vo vzt'ahu k trestnému právu hmotnému predovšetkým trestný zákonník č. 117/1852 ř. z. o zločinoch, prečinoch a priestupkoch (d’alej aj ako „rakúsky trestný zákon“). Na území

\footnotetext{
Príspevok bol spracovaný v rámci riešenia výskumného projektu APVV-16-0362: Privatizácia trestného práva hmotnoprávne, procesnoprávne, kriminologické a organizačno-technické aspekty.
} 
Slovenska a Podkarpatskej Rusi platili predpisy uhorské, hlavne zák. čl. V/1878 - Trestný zákon o zločinoch a prečinoch (d’alej aj ako „uhorský trestný zákon“) a zák. čl. XL/1879 Trestný zákonník o priestupkoch (d’alej v texte aj ako „uhorský zákonník o priestupkoch). Počas existencie 1. ČSR prebiehali intenzívne snahy o unifikáciu jednotlivých právnych odvetví, trestné právo nevynímajúc. V predloženom článku sa zameriame na stručnú charakteristiku pokusov o unifikáciu trestného práva hmotného po vzniku republiky, so zameraním pozornosti na rozdelenie trestných činov podl'a ich závažnosti v návrhoch jednotlivých trestných zákonov, ako aj v dobovej právnej vede. Návrhy kategorizácie trestných činov mali prirodzene rôzne hmotnoprávne, ale aj procesnoprávne dôsledky.

\section{DRUHY TRESTÝCH ČINOV PODLA UHORSKEJ A RAKÚSKEJ PRÁVNEJ ÚPRAVY}

Uhorský, ako aj rakúsky trestný zákon, ktoré platili na našom území po vzniku 1. ČSR vychádzali z koncepcie delenia trestných činov na zločiny, prečiny a priestupky. Pôvod tripartície trestných činov pochádzal z francúzskeho Code Penal. ${ }^{2}$ Uhorský trestný zákon upravoval rozdelenie trestných činov vo svojom Diely I. (Všeobecné ustanovenia), Hlave I. (Úvodné ustanovenia). Podl'a $§ 1$ ods. 1 zločinom alebo prečinom je len čin, ktorý zákon za taký vyhlásil. Uhorská právna úprava $\mathrm{v}$ tomto ustanovení upravovala zásadu nullum crimen sine lege. Zásada nulla poena sine lege bola upravená v nasledujúcom odseku. Podl’a $\S 1$ ods. 2 trestného zákona pre zločin alebo prečin nemožno nikoho trestat' iným trestom, ako ktorý naň ustanovil zákon pred jeho spáchaním. Úprava priestupkov na území Slovenska a Podkarpatskej Rusi bola spracovaná v osobitnom trestnom zákonníku o priestupkoch, zák. čl. XL/1879. Predmetná úprava priestupkov, ktoré sa nachádzali, na rozdiel od úpravy rakúskej, v osobitnom zákone, vychádzala už zo skorších uhorských vzorov. ${ }^{3}$ Trestný zákonník o priestupkoch sa skladal z dvoch častí (Všeobecné ustanovenia, O druhoch priestupkov a trestoch za ne). Trestami za priestupky boli podl'a $\S 15$ uhorského zákonníka o priestupkoch uzamknutie a peňažitý trest. Vonkajším znakom oddel'ujúcim zločiny od prečinov bol podl'a uhorskej právnej úpravy druh trestu stanovený zákonom. Trest smrti, trestnicu a žalár bolo podl'a $\S 20$ trestného zákona možné udelit' iba za zločiny. Uhorská právna úprava však nemala pevnú resp. nemennú hranicu medzi zločinmi a prečinmi. Zákon v určitých prípadoch súdu umožňoval, aby za zločiny boli uložené tresty, ktoré boli ukladané za prečiny. Ak takto súd rozhodol, dochádzalo aj k zmene právnej kvalifikácie konania resp. činu a vinník trestného činu sa takýmto spôsobom odsudzoval na miesto zločinu na prečin. ${ }^{4}$

2 Bližšie pozri: MILOTA, A.: Trestní právo hmotné, část obecná, (nástin prednášek), Nákladom autora, Bratislava, 1933, str. 33., SOLNAŘ, V. - FENYK, J. - CÍSAŘOVÁ, D.: Základy trestní odpovědnosti (podstatně přepracované a doplněné vydání), Nakladatelství Orac, Praha 2004, str. 50., alebo MILOTA, A.: Reforma trestního zákona v Československu, Právnická jednota na Slovensku a Podkarpatskej Rusi, Bratislava, 1934, str. 43.

3 V tejto súvislosti pozri napr.: BEŇA, J. - GÁBRIŠ, T.: Dejiny práva na Slovensku I., Univerzita Komenského v Bratislave, Právnická fakulta, Bratislava, 2015, str. 252.

4 Predmetné zmeny pri ukladaní trestov sa v uhorskom trestnom zákone v zásade týkali ustanovení §66, §72 a §92. Podl’a uhorskej právnej úpravy platnej na Slovensku sa mal pokus trestného činu podla § 66 trestného zákona vždy trestat' miernejšie ako dokonaný zločin alebo prečin. Podl’a $§ 66$ ods. 2 trestného zákona bolo možné trest za pokus uložit’ i pod najnižšiu hranicu trestnej sadzby, stanovenej na dokonaný zločin alebo prečin, či uložit' i miernejší druh trestu, ako ktorý je uvedený v zákone. Podla $§ 66$ ods. 3 v prípadoch kde sa stanoví v zákone na dokonaný zločin trest smrti alebo doživotnej trestnice, mal byt' pokus potrestaný trestnicou dočasnou; táto však nesmela byt' pri zločinoch trestných smrt’ou kratšia ako pät' rokov, pri zločinoch trestných doživotnou trestnicou kratšia ako tri roky. § 72 trestného zákona stanovoval, že pomocníkom sa stanovoval trest podl’a ustanovení $§ 66$ o pokuse. Podl'a $\S 92$ ods. 1 uhorského tr. z. ak boli pol'ahčujúce okolnosti tak závažné alebo početné, že by aj najnižšia výmera trestu určeného na čin bola nepomerne t’ažká, mohol byt' uvedený druh trestu znížený na najnižšiu mieru, a keby aj tá bola príliš prísna, mohol byt' uložený namiesto dočasnej trestnice žalár, namiesto žalára väzenie a namiesto väzenia peňažný trest, a to aj v najnižšej výmere týchto druhov trestov. 
Podl'a rakúskej právnej úpravy sa za zločin, prečin alebo priestupok mohlo pokladat' a trestat' iba to, čo sa v zákone výslovne za zločin, prečin alebo priestupok prehlasuje (čl. IV rakúskeho trestného zákona). Podl'a systematiky rakúskeho trestného zákona boli zločiny upravené v jeho Diely I. (O zločinoch) - podl'a $§ 1$ sa na spáchanie zločinu vyžadoval zlý úmysel. Diel II. (O prečinoch a priestupkoch) upravoval Hlavu I. (O prečinoch a priestupkoch a ich trestaní). Podl'a $\S 233$ prečiny a priestupky, ktoré sú obsahom tohto dielu trestného zákona, sú napospol činy alebo opomenutia, ktoré každý sám od seba za nedovolené môže poznat'; alebo také, kde páchatel' podl'a svojho stavu, svojej živnosti, svojho zamestnania alebo podl'a svojich pomerov je povinný poznat' zvláštne nariadenia, ktoré boli porušené. Preto sa na neznalost' tohto trestného zákona, čo sa týka v ňom obsiahnutých prečinov a priestupkov, nikto nemôže ospravedlňovat'. Vonkajším znakom zločinu podl'a rakúskej právnej úpravy bol rovnako, ako pri úprave uhorskej, druh trestu. Za zločiny sa podl'a $§ 12$ rakúskeho trestného zákona ukladal trest smrti alebo žalár (t’ažký žalár, žalár). Na rozdiel od uhorskej úpravy boli hranice medzi zločinmi a prečinmi pevné a súd nemal možnost' zmeny trestov tak, ako to upravovala vyššie uvedená uhorská právna úprava.

\section{ROZDELENIE TRESTNÝCH ČINOV V NÁVRHOCH TRESTNÝCH ZÁKONOV 1. $\check{C} S R$}

Snahy o prekonanie dualizmu a unifikáciu trestného práva $\mathrm{v}$ medzivojnovej republike samozrejme vo svojich návrhoch reflektovali aj koncepčné otázky pojmu a delenia trestných činov. Pokusy o prekonanie dualizmu sa začali v roku 1920, kreovaním komisie ktorá pracovala na návrhu trestného zákona. Výsledkom ich práce bola, už v roku $\underline{1921}$, vypracovaná a zverejnená osnova všeobecnej časti trestného zákona. Otázka rozdelenia trestných činov bola spracovaná v Hlave I. (Trestné zákony $(\S 1-\S 13)$, v jej prvom paragrafe. Podl'a $§ 1$ ods. 1 návrhu všeobecnej časti trestného zákona môže byt' potrestaný iba ten, kto sa dopustil činu, ktorý zákon prehlásil za trestný (súdom). Išlo o zachovanie zásady nullum crimen sine lege. Podl'a ods. 2 trestné činy, ktoré neboli prehlásené za priestupky, sú prečiny. Zločiny boli podl'a návrhu zákona, ak za nich bol stanovený trest žalára a ak súd uložil páchatel'ovi tento trest. Trest žalára mohol byt' podl'a návrhu zákona uložený, ak bol čin spáchaný z hrubej zištnosti, surovosti, záhal'čivosti, nehanebnosti, zlomysel'nosti alebo inej nízkej pohnútky.

Rozdelenie trestných činov podl’a ich závažnosti sa autori vypracovaného návrhu rozhodli, podl'a ich slov, spracovat' čiastočne odlišne od bývalej rakúskej resp. uhorskej úpravy. Autori vychádzali - vo vzt'ahu k návrhu trestného zákona - podl'a odôvodnenia návrhu, už dokonca čiastočne z bipartície trestných činov - trestné činy sa v návrhu všeobecnej časti trestného zákona delili na zločiny a prečiny. Predmetná bipartícia (vyslovene uvádzaná v odôvodnení vypracovaného návrhu všeobecnej časti trestného zákona) však zrejme mohla byt' vnímaná jednak v zmysle vnímania delenia trestných činov (zločiny a prečiny), ako aj v zmysle delenia na jednej strane činov kriminálnej povahy od iných protispoločenských konaní (priestupkov) ${ }^{5}$. Autori ako súčast' predloženej osnovy všeobecnej časti trestného zákona, vypracovali aj návrh všeobecnej časti priestupkového zákona, ktorý sa skladal zo 17 paragrafov. Všeobecná zásada, ktorá určovala vzájomný vzt’ah týchto dvoch návrhov vychádzala z konceptu, že ak nie sú stanovené odchýlky, budú platit', aj na stíhanie priestupkov, všeobecné ustanovenia

\footnotetext{
Odôvodnenie návrhu trestného zákona si v tejto časti, vo vzt’ahu k deleniu trestných činov do určitej miery dokonca protirečí, ked' v texte nie celkom presne resp. jednoznačne uvádza bipartíciu (s odkazom na úpravu v nórskom, holandskom, talianskom trestnom zákone a švajčiarskej osnove zákona), ale aj (samoyrejme „reálnu“) tripartíciu trestných činov - pozri Odůvodnění k „Zatímnému návrhu obecné části trestního zákona“ z roku 1921, Vydalo Ministerstvo spravedlnosti Československé republiky, Nákladem Ministerstva spravedlnosti, Praha, 1921, str. 1 a 2.
} 
trestného zákona o zločinoch a prečinoch. Odôvodnenie všeobecnej časti trestného zákona v súvislosti s rozdelením trestných činov uvádzalo, že osnova „roztriedila trestné činy na skupinu činov povahy kriminálnej, porušujúcich alebo ohrozujúcich právne statky závažným spôsobom, a na skupinu deliktov, ktoré túto povahu nemajú, ktoré je však tiež predsa nutné stíhat trestom zdôvodov ochrany verejného poriadku. "6, uvádzajúc d’alej, že „týmto spôsobom dochádza osnova, určite vúplnej zhode smravným presvedčením l’udu, k tripartícii, určite však iného rázu, než ako bola realizovaná v zákone rakúskom a uhorskom a než je tomu v takých nových kodifikačných prácach, ktoré ju preberajú. "7

Rozdelenie trestných činov na zločiny a prečiny bolo primárne vedené spáchaním činu z nízkej pohnútky. Návrh zákona ako príklady nízkej pohnútky uvádzal čin spáchaný z hrubej zištnosti, surovosti, záhal'čivosti, nehanebnosti, alebo napríklad zlomysel'nosti. Takýto čin bol zločinom. Podl'a vypracovaného návrhu všeobecnej časti trestného zákona mal byt' súd vždy povinný skúmat' pohnútku činu, ktorá predstavovala t'ažisko odlíšenia týchto trestných činov. Rovnaké skutkové podstaty tak mohli byt', podl'a návrhu všeobecnej časti trestného zákona, klasifikované ako zločiny (ak boli spáchané z nízkej pohnútky), ale aj ako prečiny (v prípade ak páchatel' nekonal z dôvodov nízkej pohnútky). Odôvodnenie osnovy všeobecnej časti trestného zákona sa $\mathrm{v}$ tomto prípade opakovane odvolávalo aj na tzv. „mravné presvedčenie ludu“, v súlade s ktorým, bolo podl'a autorov osnovy, takéto odlíšenie dvoch kategórií trestných činov. Rozdiel bol však zároveň určovaný samotným trestaním protiprávneho konania. O zločiny išlo podl'a návrhu zákona vtedy, ak za nich bolo možné uložit' trest žalára a súd páchatel'ovi tento trest aj uložil. „Rozdiel zločinov a prečinov bude sa javit' tiež v treste, pretože za zločiny súd uloži t’ǎ̌ši trest žalára s difamujúcimi následkami, a na prečiny l'ahší trest väzenia bez týchto následkov. Tím bude prevedený tento rozdiel do dôsledkov tak, že už $z$ trestu, a podl'a okolností aj z miesta, kde bude vykonaný, bude možno posudzovat' mravnú akost' páchatel'a. "8 Podl'a odôvodnenia vypracovanej osnovy mal byt' teda druh trestu aj akousi „technickou pomôckou“, podl'a ktorej bude možné prakticky realizovat' a odlíšit' predmetné teoretické vymedzenie rozdielov medzi trestnými činmi. Zločinmi sa tak teoreticky stávali jednak trestné činy, za ktoré zákon ukladal výhradne trest žalára (a teda zákon označoval túto kategóriu trestných činov priamo za zločiny), ako aj trestné činy, ktoré sú takto klasifikované súdom, uznajúc, že trestný čin bol spáchaný z nízkej pohnútky.

Jeden z prvých publikovaných odborných článkov, ktorý sa zaoberal aj problematikou rozdelenia trestných činov v návrhu všeobecnej časti trestného zákona, bol článok predsedu komisie, ktorá pracovala na tomto návrhu - prof. Dr. Augusta Miřičky. Vo svojom článku vo vzt'ahu k deleniu trestných činov oboznamoval verejnost' so samotným delením činov, zameriavajúc svoju pozornost' primárne na problematiku nízkej pohnútky, alebo trestania trestných činov. Podl'a prof. Miřičku, tak v zhode s vypracovaným návrhom „nie spôsob a stupeň poruchy alebo ohrozenie právneho statku, ale to, čo primälo páchatel'a $k$ jeho protisociálnemu chovaniu, teda motív činu a ním prejavené zmýšl’anie má rozhodovat'o tom, či je potrebné jeho čin prehlásit' za zločin. Trestný čin, ktorý nevzišiel z nízkej pohnútky, ktorý teda nesvedči o nízkom zmýšl'aní vinníka, hoci spôsobil vel'mi značnú škodu l'udskej spoločnosti, má síce podl'a okolností byt' potrestaný dlhoročným trestom odñatia slobody, ale páchatel'a nemá postihnút' zneuctujúci trest za zločin, on nemá byt' stigmatizovaný ako zločinec. "9

\footnotetext{
Odůvodnění k „Zatímnému návrhu obecné části trestního zákona“ z roku 1921, Vydalo Ministerstvo spravedlnosti Československé republiky, Nákladem Ministerstva spravedlnosti, Praha, 1921, str. 1.

7 Tamtiež, str. 3.

8 Tamtiež, str. 2.

9 MIŘIČKA, A.: Osnova československého zákona trestního, In: PRÁVNÍK (Časopis venovaný vědě právní a státní), Právnická jednota v Praze, Ročník LXI, Praha, 1922, str. 2.
} 
Návrh všeobecnej časti trestného zákona bol prostredníctvom unifikačného ministerstva predložený, okrem iného, aj komisii slovenských právnikov pre odbor trestného práva v Bratislave. Predmetná komisia bola zriadená a schádzala sa za účelom analýzy predloženého návrhu a jeho komparácie s právom slovenským (predtým uhorským). Z časového hl'adiska nebolo možné prechádzat' na predmetných poradách predloženú osnovu po každom paragrafe. Na návrh unifikačného ministerstva sa preto pozornost' sústredila hlavne na otázky „zásadného rázu“, problematiku, pri ktorej sa predložený návrh výraznejšie odlišoval od platných právnych poriadkov a ktorá bola, aj vzhl'adom na už zaslané námietky, prípadne sporná. Medzi sporné otázky patrilo aj delenie trestných činov. Stretnutia komisie slovenských právnikov boli formálne rozdelené na dve časti. Problematika delenia trestných činov bola preberaná na prvom zasadnutí, ktoré sa uskutočnilo 2. mája 1924 v Bratislave a ktoré viedol predseda komisie vrchný štátny zástupca A. Kissich. Práve spáchanie činu z nízkej pohnútky, ktoré malo podl'a návrhu osnovy byt' určitým kritériom rozlíšenia medzi zločinmi a prečinmi, bolo hlavným predmetom rokovania komisie $\mathrm{v}$ tejto otázke. ${ }^{10}$ Organizačne zasadnutia komisie slovenských právnikov prebiehali tak, že najprv boli prednesené jednotlivé návrhy osnovy, o ktorých sa rokovalo. Následne boli účastníci zasadnutí stručne oboznámení s jednotlivými posudkami, názormi, stanoviskami, ktoré boli v predmetnej veci doručené ministerstvu spravodlivosti prípadne unifikačnému ministerstvu. Je možné konštatovat', že so stanoviskom osnovy k rozdeleniu trestných činov $\mathrm{v}$ zásade súhlasila a nemala námietky iba generálna prokuratúra. ${ }^{11}$ Pri samotnom zasadnutí komisie k predmetnej otázke priamo vystúpili viacerí účastníci. ${ }^{12}$ Všetci, s výnimkou prof. Milotu a Dr. Slávika, prezentovali určité výhrady k navrhovanej úprave nízkej pohnútky. Tieto sa v zásade týkali nevhodnosti tejto, primárne vnútornej stránky činu, byt' kritériom, podl’a ktorého sa trestné činy mali rozlišovat'. Komisia sa na záver svojho rokovania v predmetnej otázke teda nezhodla s predkladaným návrhom trestného zákona. Nízka pohnútka nebola komisiou vyhodnotená ako správne rozlišovacie kritérium. Formálnym záverom komisie bolo odporúčanie, aby „kvalifikácia trestného činu nebola závislou na výroku sudcu; zákon sám nech urči kvalifikáciu každého činu, k pohnútke nech sa prihliada pri ukladaní trestu. "13

V roku 1926 Ministerstvo spravodlivosti tlačou vydalo Prípravné osnovy trestného zákona o zločinoch a prečinoch a zákona priestupkového. Tento návrh trestného zákona vychádzal z všeobecnej osnovy trestného zákona vypracovanej v roku 1921. Z hl'adiska systematiky návrhu bolo rozdelenie trestných činov spracované v Hlave II. (Trestné činy), oddelení I. rozdelenie trestných činov. Podl’a $§ 14$ ods. 1 návrhu trestného zákona trestný čin, ktorý nie je prehlásený za priestupok, je prečin alebo zločin. Podl’a $§ 14$ ods. 2 návrhu trestný čin, za ktorý je stanovený trest žalára, je zločin. Trestný čin, za ktorý je stanovený iný trest je prečin. $§ 14$

10 Knižné vydanie rokovaní komisie uvádza bod 1. prvého zasadnutia komisie pod názvom „Nízka pohnútka ako delítko medzi zločinom a prečinom“ - NOŽIČKA, J. (sp.): Zatímní návrh obecné části trestného zákona (záznamy z porad slovenské komise pro obor práva trestního v Bratislavě), Ministerstvo pro sjednocení zákonuv a organisace správy spolu s Právnickou jednotou na Slovensku v Bratislavě, Praha, 1924, (vyšlo nákladom ministerstva pre zjednotenie zákonov a organizácie správy ako „Príloha vestníka ministerstva pre zjednotenie zákonov a organizácie správy), str.6.

11 Podl’a záznamov z predmetných porád komisie boli účastníci zasadnutia oboznámení s posudkami, ktoré podali: Najvyšší súd československej republiky, Najvyšší vojenský súd, Generálna prokuratúra, prof. Dr. Rittler, Dr. Joklík, sudca Dr. Drbohlav, prof. Dr. Engliš, prof. Dr. Sedláček, advokát Dr. Stránský a posudkom, ktorý bol doručený pod značkou „Dr. A. G."

12 Na zasadnutí vystúpili Dr. Rippely, Dr. Stránský, Dr. Fundárek, Dr. Milota, min. rada Schrotz, Dr. Slávik, vrchný štátny zástupca Kissich a bolo prečítané vyjadrenie neprítomného sudcu Dr. Benkeho.

13 NOŽIČKA, J. (sp.): Zatímní návrh obecné části trestného zákona (záznamy z porad slovenské komise pro obor práva trestního v Bratislavě), Ministerstvo pro sjednocení zákonuv a organisace správy spolu s Právnickou jednotou na Slovensku v Bratislavě, Praha, 1924, (vyšlo nákladom ministerstva pre zjednotenie zákonov a organizácie správy ako „Príloha vestníka ministerstva pre zjednotenie zákonov a organizácie správy), str.18. 
ods. 3 upravoval skutočnost', že trestný čin, za ktorý je stanovený alternatívne trest žalára alebo iného trestu, sa trestá ako zločin žalárom, ak bol spáchaný z dôvodu tzv. nízkeho zmýšl'ania. $Z$ nízkeho zmýšl'ania bol podl'a autorov návrhu čin spáchaný hlavne, ak sa ním prejavuje hrubá zištnost', záhal'čivost', zlomysel'nost', nehanebnost', surovost', alebo ak je vinníkovi prostriedkom k tomu, aby spáchal alebo si ul'ahčil iný zločin, alebo aby si zaistil prospech zo zločinu, alebo sa uchránil pred trestom za zločin. Podl'a $\S 14$ ods. 4 priestupkom sa podl'a tohto zákona rozumie iba priestupok trestaný súdom.

Z vypracovaného návrhu trestného zákona z roku 1926 je zrejmé, že autori upravili otázku rozdelenia trestných činov čiastočne odlišne, než tomu bolo v prípade návrhu všeobecnej časti trestného zákona z roku 1921, z ktorej vo všeobecnosti vychádzali. V návrhu bola zachovaná tripartícia trestných činov $-\S 14$ návrhu upravoval zločiny, prečiny a priestupky. Predmetná tripartícia však mala, rovnako ako b prípade návrhu z roku 1921, vychádzat' z odlišných kritérií než tomu bolo v prípade úpravy rakúskej a uhorskej. Priestupky mali byt' rovnako zahrnuté a upravené v osobitnej časti návrhu, zákone o priestupkoch. Návrh úpravy $§ 14$ ods. 4 vychádzal z koncepcie priestupku, ktorý je trestaný súdom. Rovnako tak tomu bolo aj v návrhu všeobecnej časti trestného zákona z roku 1921. Išlo však iba o dočasné opatrenie. Autori vychádzali z predpokladu, že v budúcnosti sa uskutoční reforma správy a dôjde ku vybudovaniu sústavy správneho trestného súdnictva. ${ }^{14}$ Trestanie takýchto priestupkov by malo byt' následne zverené správnym súdom, takže trestné súdy by mali, po realizovanej reforme, súdit' už iba činy kriminálnej povahy, a teda iba zločiny a prečiny. ${ }^{15}$

Návrh trestného zákona z roku 1926 rovnako pri delení trestných činov na zločiny a prečiny vychádzal z konceptu zohl'adnenia vnútornej stránky činu, pri hodnotení trestných činov sa mala zohl'adňovat' subjektívna stránka. Pojem nízkej pohnútky z návrhu z roku 1921 tu bol nahradený pojmom tzv. „nizkeho zmýšl’ania“. Autori medzi dôvody spáchania činu z takéhoto subjektívneho impulzu radili prípady, ak bol čin spáchaný hlavne, ak sa ním mala prejavit' hrubá zištnost', záhal'čivost', zlomysel'nost', nehanebnost', surovost', alebo ak bol čin vinníkovi prostriedkom $\mathrm{k}$ tomu, aby spáchal alebo si ul'ahčil iný zločin, alebo aby si zaistil prospech zo zločinu, alebo sa uchránil pred trestom za zločin. Oproti návrhu z roku 1921, došlo okrem zmeny terminologického ukotvenia nízkej pohnútky, aj k rozšíreniu dôvodov, ktoré príkladmo poukazovali na konanie z nízkeho zmýšlania (ak bol čin vinníkovi prostriedkom k tomu, aby spáchal alebo si ul'ahčil iný zločin, alebo aby si zaistil prospech zo zločinu, alebo sa uchránil pred trestom za zločin). Autori v odôvodnení predkladaného návrhu trestného zákona stručne odôvodňujú rozdiel medzi nízkou pohnútkou a nízkym zmýšl’aním. ${ }^{16}$ Predložený koncept bol však v zásade rovnaký, vychádzal zo subjektívneho hl'adiska, zohl'adňujúc psychické prvky ovplyvňujúce konanie páchatel'a. ${ }^{17}$ Následkom takéhoto delenia trestných činov bolo aj upravenie rôznych sankcií trestných činov. Trestný čin mohol byt' vyhodnotený ako zločin, ale aj prečin, a to na základe rozhodnutia súdu v tom ktorom

14 Pozri aj: POŠVÁ̌̌, J.: Nástin správního práva trestního (Studie o některých pojmech, zejména o vině), Sbírka spisů právnických a národohospodářských, svazek LXXXI., Nakladatelství ORBIS Praha, Praha - Brno, 1936.

15 Př́ípravné osnovy trestního zákona o zločinech a přečinech a zákona přestupkového, II. Odůvodnění osnov, vydala Komise pro reformu československého trestního zákona, nákladem Ministerstva spravodlivosti, Praha,1926, str. 16.

16 Podl’a odôvodnenia návrhu „Osnova rozširujúc toto kritérium v záujme účelnej represie na celý odbor trestného práva, stavia namiesto nizkej a nečestnej pohnútky činu, ktorú ešte osnova z r. 1921 prehlásila za rozhodujúcu, nizke zmýšlanie vinníka. Tým má byt' povedané, že pri posudzovaní jeho činu nemá byt' iba izolovane pozorovaná jeho pohnútka, ale že má byt' skúmané, či táto pohnútka zodpovedá celkovej povahe páchatel'a. To tiež vyplýva z jednotlivých indícii nizkeho zmýšlania uvedených príkladmo $v$ \& 14 ods. 3. “ - pozri Př́pravné osnovy trestního zákona o zločinech a přečinech a zákona přestupkového, II. Odůvodnění osnov, vydala Komise pro reformu československého trestního zákona, nákladem Ministerstva spravodlivosti, Praha,1926, str. 17.

17 V tejto súvislosti pozri aj napr. SOLNǍ̌, V. - FENYK, J. - CíSAŘOVÁ, D.: Základy trestní odpovědnosti (podstatně přepracované a doplněné vydání), Nakladatelství Orac, Praha 2004, str. 53 - kde autori v súvislosti s delením trestných činov podla ich závažnosti, v návrhoch všeobecnej časti trestného zákona z r. 1921 a návrhom trestného zákona z roku 1926 konštatujú, že „,deliacim kritériom prvých dvoch osnov bola pohnútka“. 
konkrétnom prípade, zohl'adňujúc práve existenciu nízkeho zmýšl’ania páchatel'a. Rozhodnutie sudcu o druhu trestného činu malo následne vplývat' na uloženie trestu. ${ }^{18}$

Podobne ako návrh všeobecnej časti osnovy trestného zákona z r. 1921, bol aj návrh z roku 1926 predmetom viacerých analýz, článkov. Niektoré z nich, v časti týkajúcej sa triedenia trestných činov, sa svojou argumentáciou stavali hlavne proti navrhovanému deliacemu kritériu. Prof. Milota vo svojom článku uverejnenom v Právnom obzore, reagoval na dve pojednávania, kde vo vzt’ahu ku kritike navrhovaného delenia trestných činov okrem iného konštatoval, že „podl'a osnovy však roztriedenie trestných činov kriminálnej povahy na zločiny a prečiny nemá za účel stanovit' stupnicu deliktov, podl'a ktorej by boli zločiny t’ažšie trestné činy a prečiny l'ahšie; ale týmto rozdelením sa má dosiahnut' iba kriminálno politického výsledku; oddelenie trestancov, ktorí sa ukázali byt' zmýšlania nizkeho od trestancov, ktorí z takéhoto zmýšl'ania nekonali. Tým sa má sudcovi umožnit', aby už v rozsudku určil, či má byt' odsúdený zaradený do tej alebo onej skupiny a či má na ňom byt' vykonaný trest podl'a toho alebo oného spôsobu. Toto opatrenie má preto napomáhat' individualizácii výkonu trestu, ako požiadavky ktorý dôrazne stanovuje novodobá veda. Že sa tým dosahuje taktiež hodnotenie páchatel'a z hl'adiska mravného a sociálneho, možno považovat' len za zisk, avšak samo o sebe účelom triedenia trestných činov nie je. "19 Pomerne komplexne otázku nízkeho zmýšl'ania reflektoval v jednom zo svojich článkov aj V. Solnař, ked' rozdelil dovtedajšie námietky proti pohnútke na dve kategórie, identifikujúc námietky zásadné a praktické. ${ }^{20}$ Tieto kategórie vo svojom článku analyzoval, poukazujúc okrem iného aj na zmenu v návrhoch $\mathrm{z}$ rokov 1921 a $1926 .{ }^{21}$ O predmetnej problematike informoval verejnost' viackrát $v$ dobovej tlači (Lidových novinách) aj d’alší člen komisie J. Kallab. Spôsob delenia trestných činov nazval vo svojom článku „,novotou, ktorá vzbudí asi najviac pochybnosti'“, argumentujúc však v zásade v prospech tejto úpravy, okrem iného uviedol, že „osnovou navrhované rozlíšenie bude však mat' značný praktický význam. Predovšetkým ten, že umožní rozlíšit' oba základné typy l'udí, ktorí sa trestných činov dopúštajú, l'udí skutočne zlých od l'udí, ktorí sa skôr stali obetou neštastnej súhry okolností, nežž že by sa vich čine bola prejavila ich mravná zvrhlost'. Tým sa tiež umožní dvojaký spôsob trestania za rovnaký čin, hlavná podmienka účelného výkonu trestu. Pretože dnešný výkon trestu trpel hlavne tým, že bolo potrebné podrobovat' l'udi najrôznejšich pováh zásadne rovnakému spôsobu nakladania, následkom čoho trest býval pre jedných bezvýznamnou epizódou v živote, ak nie vitaným zaopatrením, zatial' čo pre druhých znamenal neprimeranú krutost'. Konečne umožní navrhované rozlišsenie tiež rozriešit’ závažnú otázku politických deliktov. "22 Na tému nízkeho zmýšl'ania, trestania páchatel'ov a ich miesta v návrhu trestného zákona publikoval autor aj článok v roku $1927^{23}$. Podobne prof. Kallab v inom svojom článku v Lidových novinách uviedol, že predložený návrh trestného zákona sa stal predmetom častej kritiky zo strany domácich praktikov. Táto kritika sa podl’a prof. Kallaba týkala v zásade troch hlavných vecí,

18 Bližšie pozri aj: FENYK, J. - CÍSAŘOVÁ, D.: Medziválečné trestní právo a věda trestního práva v Československu, In: Československé právo a právní věda v meziválečném období (1918-1938) a jejich místo ve střední Evropě (svazek 2), Univerzita Karlova v Praze, nakladatelství Karolinum, 2010, str. 825, alebo MILOTA, A.: Reforma trestního zákona v Československu, Právnická jednota na Slovensku a Podkarpatskej Rusi, Bratislava, 1934, str. 46 a nasl.

19 MILOTA, A.: Ke kritice ustanovení príípravné osnovy čsl. trestního zákoníka o třídení trestných činů a zavinění, In: Právny obzor, nákladom Právnickej Jednoty na Slovensku, číslo 9., ročník XVI./1933, str. 309.

20 V súvislosti s kritikou nízkeho zmýšl’ania pozri aj napr.: JOKLÍK, F.: Kritika př́ípravných osnov trestního zákona o zločinech a přečinech a zákona přestupkového, Tiskem a nákladem knihtiskárny Edvarda Leschingra, Praha, 1927, str. 9

21 SOLNAŘ, V.: Osnova trestního zákona (Několik poznámek k obecné části osnovy trestního zákona o zločinech a přečinech z r. 1925), In: PRÁVNÍK (Časopis venovaný vědě právní a státní), Právnická jednota v Praze (s podporou České akademie pro vědy, slovesnost a umění), Ročník LXV., Praha, 1926, str. 42 a nasl.

22 KALLAB, J.: Některé novoty v osnově československého trestního zákona, In: Lidové noviny, roč. 34, čís. $370,25$. července 1926, str. 2.

23 KALLAB, J.: Budoucí československý trestní zákonník, In: Lidové noviny, roč. 35, čís. 130, 13. března 1927, str. 2. 
kde jednou z nich bolo práve delenie trestných činov na zločiny a prečiny, prihliadajúc k nízkemu zmýšl'aniu páchatel'a. Práve vyhodnocovanie tohto subjektívneho aspektu súdmi, bolo častým predmetom kritiky. Podl'a prof. Kallaba ,sa namieta, že tým sa ukladá sudcovi príliš t’ažká úloha. Nehl'adiac však $k$ tomu, že pokrok vyžaduje vždy zvýšenie duševnej činnosti, že mnohé, čo dokážu dnešni chirurgovia alebo technici, sa pred pätdesiatimi rokmi zdalo úlohou nad l'udské sily, pochybujem, že zistenie páchatelovho zmýšl'ania by bolo podstatne obtiažnejšou úlohou, než úloha zistit', či páchatel' konal úmyselne alebo z hrubej nedbanlivosti, ktorú dnes každý sudca denne hladko rieši." ${ }^{24}$ V priebehu roku 1928 plánovalo Ministerstvo spravodlivosti ukončit túto fázu unifikačných snáh odovzdaním vypracovanej osnovy do Národného zhromaždenia. Proces unifikácie trestného práva hmotného z 20tych rokov 20. storočia však úspešný nebol a predmetná osnova sa nestala zákonom. $^{25}$

Pokusy o unifikáciu trestného práva hmotného v medzivojnovej Československej republike vyvrcholili v roku 1937. Pod názvom Osnova zákona ktorým sa vydáva trestný zákon bol v apríli 1937 vydaný vládny návrh trestného zákona. Predmetný návrh prirodzene vychádzal z Prípravných osnov trestného zákona o zločinoch a prečinoch a zákona priestupkového z roku 1926. V niektorých aspektoch ho však menil resp. doplńnal. Problematika delenia trestných činov bola spracovaná vo všeobecnej časti návrhu, v Hlave II. (Trestné činy). Podl'a $\S 15$ ods. 1 návrhu trestného zákona trestný čin, za ktorý zákon stanovoval trest smrti alebo trest žalára, je zločin. Ostatné súdne trestné činy, ktoré nie sú prehlásené za priestupky, sú prečiny.

Navrhovaná osnova podržala v platnosti existujúce delenia trestných činov na zločiny, prečiny a priestupky. Odklonila sa však od deliaceho kritéria návrhov trestných zákonov z roku 1921 a 1926. Zločinom mal byt', podl'a návrhu $§ 20$ Osnovy trestného zákona, ktorý upravoval otázky viny, zásadne iba úmyselný trestný čin. Vychádzajúc z konceptu, že „významu činu má byt’ úmerná tiež váha trestu, ktorý za neho zákon stanovuje “26, stanovila osnova za zločiny len úmyselné trestné činy, za ktoré zákon stanovil trest smrti alebo žalára. Týmto došlo k oddeleniu zločinov od prečinov a priestupkov aj druhom trestu. Podl'a $\S 20$ ods. 2 bol pre prečin trestný ten, kto konal úmyselne, alebo ak to zákon vyslovene upravoval, tiež ten, kto konal z nedbanlivosti. Pri úmyselnom konaní v prípade prečinu však význam konania nebol takej závažnosti, aby bol uložený trest žalára. Podobne tak konanie z nedbanlivosti, vzhl'adom na miernejší stupeň zavinenia, nemalo zakladat' označovanie ako zločiny, išlo o prečiny. Ostatné trestné činy označovala osnova ako priestupky. Návrh trestného zákona z r. 1937 tak zavrhol subjektívnu hodnotiacu líniu medzi zločinom a prečinom tak, ako bola navrhovaná v rokoch 1921 a 1926. Osnova sa však určitým spôsobom chcela vysporiadat' aj s nedostatkom vyplývajúcim zo „,strnulej hranice“ medzi zločinmi a prečinmi. Podl'a jej odôvodnenia tak „rozdelenie trestných činov na zločiny a prečiny nesmie byt' tak strnulé, aby sa dostalo do rozporu so všeobecným právnym cítením

24 KALLAB, J.: Budoucí trestní zákonník československý, In: Lidové noviny, roč. 36, čís. 394, 5. srpna 1928, str. 1.

25 V súvislosti so spracovaním stručne naznačených pokusov o unifikáciu trestného práva z 20tych rokov 20. storočia, ako aj vývojom trestného práva v skúmanom období medzivojnovej republiky pozri napr. aj: JABLONICKÝ, T.: Pokus o reformu československého trestního práva - osnova trestního zákona z let 1921-26, In: Právněhistorické studie, Praha : Karolinum, Sv. 43, 2013, str. 84 - 96, HORÁK, O.: Trestní právo medziválečného Československa (Vybrané otázky), In: Československé trestní právo v proměnách věků (Sborník př́íspevků), Masarykova univerzita, Brno, 2009, VLČEK, E.: Dějiny trestního práva v Českých zemích a v Československu, Masarykova univerzita, Brno, 2006, MALÝ K. a kolektív, Dějiny českého a československého práva do roku 1945, Linde Praha a.s., Praha, 1999, KUKLÍK, J., SKŘEJPKOVÁ, P.: Kořeny a inspirace velkých kodifikací (příspěvek k aplikaci „Principu“ E. F. Smidaka), AVENIRA Stifung, Luzern, 2008, SKŘEJPKOVÁ, P. (usp.), Antologie československé právní vědy v letech 1918 - 1939, LINDE PRAHA, Praha, 2009, alebo VOJÁČEK, L. - KOLÁRIK, J. - GÁBRIŠ, T.: Československé právne dejiny (2. prepracované vydanie), EUROKÓDEX, s. r. o., Bratislava, 2013.

26 Odůvodnění Osnovy zákona, kterým se vydáva trestní zákon, Ministerstvo spravedlnosti Československé republiky, 1937, str. 179. 
a prekážalo účelnej individualizácii previnilcov, hlavne z hl’adiska druhu a tiež aj spôsobu výkonu trestu, trestov vedl'ajších, podmienečného odsúdenia atd”. 27 Predmetné možnosti korekcií takejto úpravy vychádzali z uhorského vzoru, ked’že podobným spôsobom upravovala možnost' zmeny trestu práve uhorská právna úprava. V návrhu trestného zákona z roku 1937 bola koncepčne predmetná otázka korekcie upravená v časti zákona o ukladaní trestov, konkrétne ustanovení o zmiernení a zmene trestu. ${ }^{28}$

\section{ZÁVER}

Stav právneho dualizmu v oblasti trestného práva mal po vzniku Československej republiky v roku 1918 nepriaznivé účinky na štát a jeho obyvatel'stvo. Odbornými, ale aj laickými kruhmi bol vnímaný negatívne. V podstate od vzniku štátu prebiehali snahy o jeho prekonanie, prvé výsledky tohto procesu boli viditel'né už v roku 1921, kedy došlo k vypracovaniu návrhu všeobecnej časti trestného zákona. V roku 1926 Ministerstvo spravodlivosti tlačou vydalo Prípravné osnovy trestného zákona o zločinoch a prečinoch a zákona priestupkového. V apríli 1937 bol následne vydaný pod názvom - Osnova zákona ktorým sa vydáva trestný zákon -_vládny návrh trestného zákona.

Všetky tieto pokusy o unifikáciu trestného práva v1. ČSR vo svojich návrhoch zachovávali koncepciu tripartície trestných činov, rovnako ako tomu bolo v trestnom práve uhorskom, ako aj rakúskom. Návrhy z rokov 1921 a 1926 však boli vystavané na odlišnom koncepte. Tento pri deliacej línii medzi zločinmi a prečinmi reflektoval primárne zohl'adnenie vnútornej stránky činu, pri hodnotení trestných činov sa malo vychádzat' zo subjektívnej stránky činu. Vládny návrh trestného zákona z roku 1937 už túto subjektívnu hodnotiacu líniu nezohl'adňoval. Závažné spoločenské zmeny prebiehajúce v Československej republike na jeseň roku 1938, ktoré vyústili v marci 1939 do rozpadu republiky, však prijatie trestných

27 Odůvodnění Osnovy zákona, kterým se vydáva trestní zákon, Ministerstvo spravedlnosti Československé republiky, 1937, str. 180.

28 Podl’a $§ 65$ ods. 1 návrhu trestného zákona, namiesto žalára, tuhého väzenia (aj ako trestov náhradných) uloží súd za trestný čin, ktorý podl'a svojej povahy a podl'a okolností, za ktorých bol spáchaný, svedči o snahe vinníka realizovat' vplyv na usporiadanie vecí verejných alebo sociálnych, trest štátneho väzenia. Podl’a $§ 65$ ods. 2 súd nemôže uložit' namiesto trestu uvedeného v predchádzajúcom odseku štátne väzenie: a) ak odsudzuje za trestný čin podl’a $§ 125$ až 127 , 236, 237, 265 až 269, 282 až 284, 291 až 296, d’alej za čin trestný podl'a zákona o obrane štátu, pre podnecovanie $\mathrm{k}$ vojenskému zločinu alebo prečinu uvedenému v § 171 až 177 zákona o obrane štátu alebo k prečinu uvedenému v 47 až 51 branného zákona (\$209), pre nadržovanie osobe, ktorá sa dopustila vojenského zločinu (\$161), alebo pre čin, ktorým bola alebo mala byt' spôsobená značná škoda na verejnom alebo súkromnom majetku, b)bol čin spáchaný z pohnútky nízkej alebo nečestnej, c) ak je čin spôsobom svojho prevedenia, použitými prostriedkami alebo zavinenými následkami obzvlášt' zavrhnutiahodný. Podl’a $§ 65$ ods. 3 ustanovenie odstavca 1 použije súd aj vtedy, ak sú aspoň pri jednom zo zbiehajúcich sa trestných činov splnené podmienky pre zmenu trestu na trest štátneho väzenia, ostatné zbiehajúce sa trestné činy neboli spáchané z nízkej a nečestnej pohnútky a sú iba prečinmi nepatrného významu alebo priestupkami. Ak nie sú ostatné zbiehajúce sa trestné činy takej povahy, uloží súd trest podl'a všeobecných ustanovení, môže však, prihliadajúc k povahe zbiehajúcich sa trestných činov, vyslovit', že určitá čast' trestu bude vykonaná podl'a predpisov o výkone trestu štátneho väzenia. Podla $§ 65$ ods. 4 ak sa súd uznesie uložit' namiesto žalára štátne väzenie kratšie ako tri roky, odsúdi vinníka za prečin, a nie za zločin, a čin, za ktorý bolo namiesto žalára uložené štátne väzenie kratšie než tri roky, posudzuje sa aj nad’alej ako prečin. Podl’a $§ 66$ ods. 1 namiesto žalára uloží súd tuhé väzenie, ak závažné okolnosti svedčia o menšej trestnosti vinníka a z podstatných dôvodov je možné mat' za to, že aj tento trest postačí k polepšeniu vinníka. Podl’a $§ 66$ ods. 2 súd môže uložit' namiesto žalára tuhé väzenie: a) ak ukladá trest aspoň na tri roky, b) ak ukladá trest za čin, na ktorý zákon stanovuje trest odňatia slobody aspoň na pät’ rokov, c) ak bol čin, alebo aspoň jeden zo zbiehajúcich sa zločinov alebo úmyselných prečinov spáchaný z pohnútky nízkej a nečestnej, a ak to nie je iba prečin, za ktorý zákon stanovuje trest najviac šest' mesiacov. Podl'a $§ 66$ ods. 4 ak sa uznesie súd uložit' namiesto žalára tuhé väzenie, odsúdi vinníka za prečin, a nie za zločin, a čin, za ktorý bolo namiesto žalára uložené tuhé väzenie, posudzuje sa aj nad’alej ako prečin. Podl’a $§ 67$ ods. 1 namiesto tuhého väzenia dlhšieho než šest' mesiacov uloži súd žalár, ak je možné z podstatných dôvodov mat' za to, že sa trestom tuhého väzenia nedosiahne polepšenie vinníka, a ak je čin, za ktorý sa trest ukladá, alebo aspoň jeden zo zbiehajúcich sa trestných činov úmyselným prečinom spáchaným z pohnútky nízkej a nečestnej a trestným tuhým väzením vyšším než šest' mesiacov. Podl’a $§ 67$ ods. 2 ak sa súd uznesie uložit' namiesto tuhého väzenia žalár, odsúdi za zločin, a nie za prečin, a čin, za ktorý bol namiesto tuhého väzenia uložený žalár, posudzuje sa aj nad’alej ako zločin. To však neplatí o takých zbiehajúcich sa trestných činoch, u ktorých nie sú podmienky pre zmenu trestu podl’a predchádzajúceho odseku splnené. 
zákonov už neumožnili. Ani tento pokus o prekonanie stavu právneho dualizmu nebol úspešný.

\section{KLÚČOVÉ SLOVÁ}

trestný zákon, unifikácia trestného práva, medzivojnové Československo, rozdelenie trestných činov.

\section{KEY WORDS}

Criminal Code, unification of criminal law, interwar Czechoslovakia, types of crime offences.

\section{POUŽITÁ LITERATÚRA}

1. BEŇA, J. - GÁBRIŠ, T.: Dejiny práva na Slovensku I., Univerzita Komenského v Bratislave, Právnická fakulta, Bratislava, 2015.

2. FENYK, J. - CÍSAŘOVÁ, D.: Medziválečné trestní právo a věda trestního práva v Československu, In: Československé právo a právní věda v meziválečném období (1918-1938) a jejich místo ve střední Evropě (svazek 2), Univerzita Karlova v Praze, nakladatelství Karolinum, 2010.

3. HORÁK, O.: Trestní právo medziválečného Československa (Vybrané otázky), In: Československé trestní právo v proměnách věků (Sborník příspevků), Masarykova univerzita, Brno, 2009

4. JABLONICKÝ, T.: Pokus o reformu československého trestního práva - osnova trestního zákona z let 1921-26, In: Právněhistorické studie, Praha : Karolinum, Sv. 43, 2013.

5. JOKLÍK, F.: Kritika př́pravných osnov trestního zákona o zločinech a přečinech a zákona přestupkového, Tiskem a nákladem knihtiskárny Edvarda Leschingra, Praha, 1927.

6. KALLAB, J.: Některé novoty v osnově československého trestního zákona, In: Lidové noviny, roč. 34, čís. 370, 25. července 1926.

7. KALLAB, J.: Budoucí československý trestní zákonník, In: Lidové noviny, roč. 35, čís. 130, 13. března 1927.

8. KALLAB, J.: Budoucí trestní zákonník československý, In: Lidové noviny, roč. 36, čís. 394, 5. srpna 1928.

9. KUKLÍK, J., SKŘEJPKOVÁ, P.: Kořeny a inspirace velkých kodifikací (př́spěvek k aplikaci „Principu“ E. F. Smidaka), AVENIRA Stifung, Luzern, 2008.

10. MALÝ K. a kolektív, Dějiny českého a československého práva do roku 1945, Linde Praha a.s., Praha, 1999.

11. MILOTA, A.: Trestní právo hmotné, část obecná, (nástin prednášek), Nákladom autora, Bratislava, 1933.

12. MILOTA, A.: Ke kritice ustanovení přípravné osnovy čsl. trestního zákoníka o tř́́dení trestných činů a zavinění, In: Právny obzor, nákladom Právnickej Jednoty na Slovensku, číslo 9., ročník XVI./1933.

13. MILOTA, A.: Reforma trestního zákona v Československu, Právnická jednota na Slovensku a Podkarpatskej Rusi, Bratislava, 1934.

14. MIŘIČKA, A.: Osnova československého zákona trestního, In: PRÁVNÍK (Časopis venovaný vědě právní a státní), Právnická jednota v Praze, Ročník LXI, Praha, 1922

15. NOŽIČKA, J. (sp.): Zatímní návrh obecné části trestného zákona (záznamy z porad slovenské komise pro obor práva trestního v Bratislavě), Ministerstvo pro sjednocení zákonuv a organisace správy spolu s Právnickou jednotou na Slovensku v Bratislavě, 
Praha, 1924, (vyšlo nákladom ministerstva pre zjednotenie zákonov a organizácie správy ako „Príloha vestníka ministerstva pre zjednotenie zákonov a organizácie správy)

16. Odůvodnění $\mathrm{k}$ „Zatímnému návrhu obecné části trestního zákona“ z roku 1921, Vydalo Ministerstvo spravedlnosti Československé republiky, Nákladem Ministerstva spravedlnosti, Praha, 1921.

17. Odůvodnění Osnovy zákona, kterým se vydáva trestní zákon, Ministerstvo spravedlnosti Československé republiky, 1937.

18. POŠVÁŘ, J.: Nástin správního práva trestního (Studie o některých pojmech, zejména o vině), Sbírka spisů právnických a národohospodářských, svazek LXXXI., Nakladatelství ORBIS Praha, Praha - Brno, 1936.

19. Přípravné osnovy trestního zákona o zločinech a přečinech a zákona přestupkového, II. Odůvodnění osnov, vydala Komise pro reformu československého trestního zákona, nákladem Ministerstva spravodlivosti, Praha, 1926.

20. SOLNǍ̌, V.: Osnova trestního zákona (Několik poznámek k obecné části osnovy trestního zákona o zločinech a přečinech z r. 1925), In: PRÁVNÍK (Časopis venovaný vědě právní a státní), Právnická jednota v Praze (s podporou České akademie pro vědy, slovesnost a umění), Ročník LXV., Praha, 1926.

21. SOLNǍ̌, V. - FENYK, J. - CÍSAŘOVÁ, D.: Základy trestní odpovědnosti (podstatně přepracované a doplněné vydání), Nakladatelství Orac, Praha 2004.

22. SKŘEJPKOVÁ, P. (usp.), Antologie československé právní vědy v letech 1918 - 1939, LINDE PRAHA, Praha, 2009.

23. VLČEK, E.: Dějiny trestního práva v Českých zemích a v Československu, Masarykova univerzita, Brno, 2006.

24. VOJÁČEK, L. - KOLÁRIK, J. - GÁBRIŠ, T.: Československé právne dejiny (2. prepracované vydanie), EUROKÓDEX, s. r. o., Bratislava, 2013.

\section{KONTAKTNÉ ÚDAJE AUTORA}

\section{JUDr. Miroslav Fico, PhD.}

Odborný asistent Katedry dejín štátu a práva

UPJŠ v Košiciach, Právnická fakulta, Kováčska 26, 04001 Košice

e-mail: miroslav.fico@upjs.sk

Telefón: 055/2344131 